\title{
Isolation and Characterization of Lactic Acid Bacteria Producing GABA from Indigenous West Sumatera Fermented Food
}

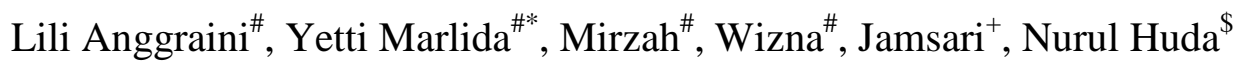

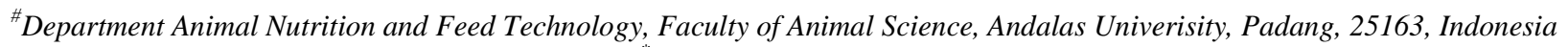 \\ E-mail: *yettimarlida@ansci.unand.ac.id \\ ${ }^{+}$Department of Crop Science, Faculty of Agriculture, Universitas Andalas, 25163, Indonesia \\ ${ }^{\$}$ Faculty of Food Science and Nutrition, Universiti Malaysia Sabah, 88400 Kota Kinabalu, Sabah, Malaysia
}

\begin{abstract}
The purpose of this study was to isolate and characterize lactic acid bacteria (LAB) from indigenous West Sumatera fermented foods. The aim was to obtain LAB isolates that have the ability to produce $\gamma$-aminobutyric acid (GABA) and to characterize the highest GABA producing LAB. The indigenous West Sumatera fermented foods sampled were dadih (fermented buffalo milk), asam durian (fermented durian), tape singkong (fermented cassava) and ikan budu (fermented fish). The conventional method was used to isolate LAB, after which LAB were screened for $\gamma$-amino butyric acid (GABA) and GABA producing LAB characterized by biochemical tests. A total of 704 isolates were successfully isolated. Five hundred fifty two (552) isolates were identified as LAB and 103 isolates were confirmed as GABA producing LAB. The highest GABA producing LAB was DS15 and produced $49.365 \mathrm{mg} / \mathrm{ml}$ of GABA. DS18 produced the least GABA of $3.415 \mathrm{mg} / \mathrm{ml}$. Biochemical assay of DS15 showed that the isolate could grow on the MRSA, undergoes aerobic respiration, do not use lactose, glucose, mannitol, arginine, aesculin, arabinose, raffinose, sorbitol, trehalase and xylose/melezitose. The isolate DS15 was also negative for arginine, nitrate reduction, catalase and oxidase tests. Based on the gram stain reaction, the isolate DS15 was a gram-positive bacterium and could be classified as Lactobacillus sp.
\end{abstract}

Keywords - lactic acid bacteria; $\gamma$-aminobutyric acid; indigenous fermented food.

\section{INTRODUCTION}

$\gamma$-Aminobutyric acid (GABA) is the major inhibitory neurotransmitter in the mammalian central nervous system (CNS) [1]. GABA is formed by decarboxylation of Lglutamate, a reaction catalyzed by an enzyme that depends on the peridoxal phosphate of decarboxylated L-glutamate. This decarboxylase enzyme is present in the central nervous system [2].

Dhakal et al., [3] reported that GABA can improve plasma concentration, growth hormones and protein synthesis in the brain, and reduce blood pressure in animals and humans. Dysfunction of the gamma-aminobutyric (GABA) in central nervous system has long been associated with anxiety disorders, such as epilepsy, anxiety, alcoholism, angelman's syndrome, autism, depression, premenstrual syndrome, sleep disorders, and alzheimer's disease [4]. For that reason, GABA is regarded as very important for physiological function in the mammalian central nervous system, induction of hypotensive, diuretic effects, and tranquilizer effects for human [5]. GABA was reported to take part in preventing heat-induced stress in broilers [6] and increasing body weight gain in pigs [7].

GABA is naturally present in animals, plants and microorganisms (bacteria, yeast and fungi) [3]. Thus GABA can be produced from a variety of microorganisms. Lactic acid bacteria (LAB) is generally regarded as safe, therefore, LAB-producing GABA can be directly used in functional foods [8]. The LAB-producing GABA has become a focus of research in recent years due to their special physiological activity and safety. Some strains of LAB are able to change glutamate and produce $\mathrm{GABA}$ and $\mathrm{CO} 2$, such reaction will produce energy that can be used for ATP synthesis [9].

Many fermented food products can be used as sources for the isolation of LAB. A number of works have reported on the isolation of LABs from different types of fermented food products such as Cheese [10], Kimchi [11], and fish [12] that could produce GABA. West Sumatera Province has many indigenous fermented food products such as dadih, asam durian, tape singkong and ikan budu that can be used as source of LAB. Isolation and screening of such LAB from naturally fermented foods of West Sumatera Province origin is rare, and novel food products often have present means for 
obtaining useful cultures for scientific and commercial purposes [13]. Therefore, this study was conducted to isolate and characterize LAB GABA from indigenous West Sumatera fermented foods.

\section{MATERIALS AND METHODS}

\section{A. Sample Collection}

Samples from indigenous fermented food products (dadih, asam durian, tape singkong and ikan budu) were collected from different traditional markets in West Sumatera, Indonesia. Dadih was collected from Aiadingin, Sijunjung and Solok, Asam durian was collected from Padang and Solok, tape singkong was collected from Bukittinggi and ikan budu was collected from Tiku. The samples were collected between June-August 2017 and analyzed at the Faculty of Animal Science Andalas University, West Sumatera, Indonesia.

\section{B. Isolation of lactic acid bacteria}

Isolation of LAB was done according to the protocol described by [14] with some modifications. Ten (10) $g$ of sample (dadih, asam durian, tape singkong or ikan budu) was mixed with $90 \mathrm{ml}$ MRS Broth (Merck, Darmstadt, Germany) in a $250 \mathrm{ml}$ Erlenmeyer flask prior to adding $2 \mathrm{~g}$ of glucose (Merck, Darmstadt, Germany). The mixture was incubated at $30^{\circ} \mathrm{C}$ at $100 \mathrm{rpm}$ for 7 days (Incubator shaker series I26, New Brunswick Scientific, United States). A dilution of 10-12 was done after incubation using aquabides. One (1) ml of diluted mixture was spread evenly in the three petri dishes containing selective media of MRS Agar (Merck, Darmstadt, Germany). All colonies were tested for the formation of clear zone by adding $2 \%$ of $\mathrm{CaCO} 3$ (Merck, Darmstadt, Germany) to the MRS agar and incubated at $30 \mathrm{oC}$ for 24 hours. Isolates that could produce clear zone in the medium were considered as LAB.

\section{Qualitative screening of $G A B A$ producing $L A B$}

Each selected LAB isolate was grown in a production medium consisting of MRS broth with the addition of 50 $\mathrm{mM}$ of L-glutamate (Merck, Darmstadt, Germany) as an inducer. Incubation was carried out at a temperature of $30^{\circ} \mathrm{C}$ under anaerobic for three days. After incubation, the media was centrifuged at $10,000 \mathrm{rpm}$ for 20 minutes at $4^{\circ} \mathrm{C}$ (Refrigerated Centrifuge TGL-20M, China). The supernatant was collected and analyzed using TLC (Thin Layer Chromatography) (Merck, Germany) to check for $\gamma$ Aminobutyric acid (GABA) production. Commercial GABA (Sigma-Aldrich, China) was used as standard and assayed on a TLC plate using n-Butanol: acetic acid: $\mathrm{H} 2 \mathrm{O}(\mathrm{v} / \mathrm{v} / \mathrm{v})$ as mobile phase. The TLC plate was subjected to a ninhydrin reagent and heated $\left(60^{\circ} \mathrm{C}\right)$ for 3-5 minutes. Spots and colors formed in this assay was compared to the standard [15].

\section{Quantitative screening of $G A B A$ producing $L A B$}

Quantitative screening was performed to determine the GABA concentrations produced during incubation. The quantification was done using the method described by Spies [16]. Aliquot from each sample was taken from $1 \mathrm{ml}$ supernatant and added to $1 \mathrm{ml}$ of $0.1 \%$ ninhydrin reagent. After which it was heated in water bath for 5 minutes, cooled under running water and the absorbance measured at $570 \mathrm{~nm}$. The GABA content in the sample was determined using GABA standard curve.

\section{E. Characterization of $G A B A$ producing $L A B$}

Characterization of $\mathrm{LAB}$ was performed according to the protocol described Gad et al., [17]. The biochemical test was conducted according to the Systematic Bacteriological Bergey's Manual [18]. The biochemical test covered: TSIA, catalase, oxidase, lactose, glucose, mannitol, VP, OF, arginine, aesculin, arabinose, raffinose, sorbitol, trehalase, maltose, melezitose, and nitrate tests.

\section{RESULTS AND DISCUSSION}

\section{A. Isolation of LAB from indigenous West Sumatera fermented food}

Fermentation is one of the oldest forms of food preservation in the word. Fermentation can improve the storability and taste of food and food products. West Sumatera has a variety of fermented foods, such as dadih, asam durian, tape singkong and ikan budu. In West Sumatera, fermented foods are produced on small scales as household business, and fermentation is done using traditional processes that are influenced by local culture. The fermentation process can occur naturally because of the microbes that are already present in these foods when they grow and/or the addition of microbial cultures which results in a more uniform product.

A total of 704 isolates were successfully identified from all the fermented food samples examined. Distribution of the isolates and the number of GABA producing LAB is presented in Table 1. Fermented milk (Dadih) obtained from Aiadingin produced the highest number of isolates (131 isolates) while tape singkong produced the least number of isolates (35 isolates). From the 704 isolates, only 552 isolates could be classified as LAB (based on the clear zone). The clear zone is formed from the reaction between lactic acid produced by LAB cell and calcium carbonate $(\mathrm{CaCO} 3)$ added to the medium. The Ca-lactic acid is seen as clear zones around the colony on the medium [19]. The present of $\mathrm{CaCO} 3$ in the growing medium is an early step of LAB detection, where $\mathrm{LAB}$ show clear zones after the incubation period [20].

LAB needs complex nutrition such as amino acids, peptides, nucleotide bases, vitamins, fatty acid, minerals and carbohydrates for their growth [21]. Variation of LAB number on each food sample is due to the differences in the characteristics of the food material used for the fermentation process. Each animal and vegetable products produce different materials, so that there are differences in nutritional content available for the bacterial growth.

Dadih is fermented buffalo milk, and it is a popular dairy product in Bukittinggi, Padangpanjang, Solok, Lima Puluh Kota and Tanah Datar [22]. Dadih obtained from Bukittinggi have a nutritional content of $7.57 \%$ protein, $6.48 \%$ fat, $3.79 \%$ carbohydrates and $81.03 \%$ moisture. Ikan budu is fermented fish product from Pasaman and has been reported to have a proximate composition of $51 \%$ moisture content, $33 \%$ protein, $0.5 \%$ fat and $14 \%$ ash [23]. 
Fermented food products derived from vegetables or plants have higher carbohydrate content. Tape singkong is made from fermented cassava, and has $32-35 \%$ carbohydrate, $0.1-0.3 \%$ fat [24] and $6.8 \%$ protein. Asam durian is made from fermented durian and contains carbohydrate $6.3 \%$, protein $8.1 \%$, and fat $6.6 \%$ [25].

TABLE I

DISTRIBUTION OF LAB ISOLATES FROM THE INDIGENOUSWEST SUMATERA FERMENTED FOOD

\begin{tabular}{|c|l|l|c|c|c|}
\hline No & Samples & Origin(s) & isolates & LAB & $\begin{array}{c}\text { Producing } \\
\text { GABA }\end{array}$ \\
\hline 1 & Dadih & Aia dingin & 131 & 125 & 24 \\
\hline & & Sijunjung & 166 & 93 & 19 \\
\hline 2 & & Solok & 100 & 96 & 19 \\
\hline 3 & $\begin{array}{l}\text { Ikan } \\
\text { budu }\end{array}$ & Pariaman & 135 & 17 & 9 \\
\hline & durian & Padang & 132 & 130 & 13 \\
\hline 4 & Tape & $\begin{array}{l}\text { Solok } \\
\text { tinggi }\end{array}$ & 75 & 59 & 9 \\
\hline
\end{tabular}

\section{B. Qualitative screening of $G A B A$ producing $L A B$}

Screening was performed to detect isolates that were capable of producing extracellular $\gamma$-Aminobutyric acid (GABA). Of the $552 \mathrm{LAB}$ isolates obtained, only 103 isolates can produce extracellular GABA (data not shown). The highest number of GABA-producing LAB isolates (24 isolates), was found in dadih obtained from Aiadingin, while the lowest number (9 isolates) was identified in asam durian from Solok and ikan budu from Pariaman. This can occur because of differences in the types of each isolate obtained, so that they have different GABA. Li et al., [26] explains that the GABA-producing ability varies widely among the strains of LAB, and some GABA-producing LAB strains have shown a great promise potential in large-scale fermentation for the production GABA.

\section{Quantitative screening of $G A B A$ producing $L A B$}

In order to identify the capability of LAB to produce GABA, putative promising isolates were further analyzed quantitatively (Table 2). The highest GABA production was shown by isolate DS15 $(49.365 \mathrm{mg} / \mathrm{ml})$, while the lowest GABA production was shown by isolate DS18 (3.415 $\mathrm{mg} / \mathrm{ml})$. Both isolates were collected from Dadih. In general, isolates collected from Dadih produced GABA in high concentration $(16.123 \mathrm{mg} / \mathrm{ml})$ compared to the other fermented foods (ikan budu, asam durian and tapai singkong) which produced $10.871 \mathrm{mg} / \mathrm{ml}, 11.035 \mathrm{mg} / \mathrm{ml}$ and 12.110 $\mathrm{mg} / \mathrm{ml}$, respectively. The GABA production capability shown by DS15 was higher than that described by [27] from Lactobacillus brevis NCL912 $(35.662 \mathrm{mg} / \mathrm{ml})$.

GABA is formed by decarboxylation of L-glutamate, a reaction catalyzed by an enzyme dependent on pyridoxal phosphate [2]. Glutamate decarboxylase (GAD) is also produced by several microorganisms such as LAB. Research conducted by Marlida et al., [28] found a LAB that produced glutamate from dadih with GABA as the precursor. GABA biosynthesis in microorganisms is regulated by several factors that will affect the fermentation process. These factors are $\mathrm{pH}$, temperature, time of the fermentation process, the nutrient content such as carbon and nitrogen, and inducer. The optimum conditions of fermentation from each bacterium could be different, this is due to differences in GAD enzymes catalyzing glutamic acid to GABA. Therefore, the characteristics of microorganisms especially LAB in producing GABA need to be elucidated in order to help achieve high GABA production.

TABLE II

GABA PRODUCTION OF ISOLATES COLLECTED FROM DIFFERENT FERMENTED FOOD SOURCES

\begin{tabular}{|l|l|l|}
\hline No & Name of Isolates & Gaba yield $(\mathrm{mg} / \mathrm{ml})$ \\
\hline 1 & Da .9 & 29.12 \\
\hline 2 & Da.16 & 22.91 \\
\hline 3 & Da.20 & 29.82 \\
\hline 4 & Da.21 & 44.15 \\
\hline 5 & Da.24 & 35.02 \\
\hline 6 & Ds.2 & 42.34 \\
\hline 7 & Ds.3 & 31.52 \\
\hline 8 & Ds. 15 & 49.40 \\
\hline 9 & Ap. 8 & 22.62 \\
\hline 10 & Ap. 5 & 16.12 \\
\hline
\end{tabular}

\section{Characteristic of $G A B A$ producing $L A B$}

Since DS15 showed the highest GABA production (Table 2), further analysis was undertaken on this isolate (Table 3). The isolate DS15 was tested for its oxygen requirement, and the isolate was found to be aerobe or grow under oxygen conditions. $\mathrm{LAB}$ is a type of microorganism that prefers to grow under anaerobic conditions, but LAB can also grow under oxygenated conditions, also called anaerobic aerotrophic bacteria [21]. So, it can be concluded that the whole bacterial isolate is anaerobic aerotolerant.

TSIA Test (Triple Sugar-Iron Agar) is used to determine the ability of bacteria to ferment lactose, glucose and to produce acids. This ability is based on the carbohydrate fermentation pathway. In the TSIA test, when the color of the media turns red at the top and bottom (M/M), it indicates the absence of carbohydrate fermentation, when it turns red at the top and yellow at the bottom $(\mathrm{M} / \mathrm{K})$, it indicates the bacteria can decompose glucose, and when the media turns yellow at the top and bottom (K/M), the bacteria is said to ferment lactose and/or sucrose [29]. TSIA test for DS15 isolate showed red at the top and bottom (M/M), which means that, DS15 does not use glucose, lactose and sucrose as a source of energy. This can happen because of the many other carbon sources that can be utilized by bacteria as a source of energy. In addition, bacteria also use nitrogen such as amino acids and peptides as an energy source.

The catalase test was performed to distinguish microorganisms that have catalase enzymes used to dexter hydrogen peroxide which is toxic [30]. Catalase reaction is positive when there is formation of air bubbles, which indicates the formation of $\mathrm{O}_{2}$ gas, and negative if it does not indicate the presence of gas bubbles. DS15 was not able to produce the catalase enzyme to convert hydrogen peroxide $/ \mathrm{H}_{2} \mathrm{O}_{2}$ into water and oxygen, which is one of the characteristics of lactic acid bacteria [31]. Therefore, DS15 it's a catalase negative bacterium. Similarly with Guessas and Kihal [32] found that nine lactic acid bacteria isolated from fermented goat milk were catalase negative. Adam and 
Nout [33] also indicated that there are some lactic acid bacteria that show negative results for catalase.

The oxidation test was performed to test the activity of the bacterial cytochrome oxidase [34]. Aerobic and facultative anaerobic bacteria will exhibit oxidase activity. The oxidase enzyme plays a role in the electron transport system during aerobic respiration. Cytochrome oxidase will catalyze the oxidation of the reduced cytochrome by oxygen producing $\mathrm{H}_{2} \mathrm{O}$ and $\mathrm{H}_{2} \mathrm{O}_{2}$ [35]. DS15 was negative for oxidase test (Table 3), that is, no color change occurred when paminodimethylaniline oxalate reagents were added. The reagent acts as an electron donor and will oxidize to a black compound if there is free oxidase and oxygen.

Starch hydrolysis test (mannitol, aesculin, arabinose, raffinose, sorbitol, trehalase, maltose and melezitose) is used to determine the bacterial ability to excrete extracellular enzymes. Agar starch composed of nutrient agar with starch substrate and an indicator is used to test starch hydrolysis. Hydrolysis of starch is shown by differences in color change [34], [35]. For instance, aesculin media will turn black if bacteria are able to ferment it. From Table 3, D15 was negative for lactose, glucose, arginine, aesculin, arabinose, raffinose, sorbitol, trehalase, xylose and melezitose. Generally, bacteria use simple sugars as carbon sources, but if simple sugars are not available then bacteria will use complex sugars as a carbon source in fermentation [35].

The VP test (Voges-Proskauer) is used to determine the ability of a bacterium to produce non-acidic substances or neutral end products, such as acetylmethylcarbinol from organic acids because of glucose metabolism [30], [34]. DS15 showed negative result for VP test. This is because there was no color change of the medium to red caused by the catalyst reaction of $\alpha$-naphthol and guanidine group present in peptone from test medium (MR-VP) with reagent Barrit's [29].

Amino acid test is perform to determine the ability of bacteria to degrade amino acid substrates. Alpha amino acid is composed of carbon (-C-), amino group $\left(-\mathrm{NH}_{2}\right)$, a carboxylic group $(-\mathrm{COOH})$ and hydrogen atom $(-\mathrm{H})$. Amino acid substrate undergoes decarboxylation (catalyze by decarboxylase enzyme with the elimination of the carboxylic group) to produce an amine or diamine and carbon dioxide. Amines are then used to synthesize the various molecules required by the cell. The final production of the amine will result in a change in $\mathrm{pH}$. Tests using the amino acid arginine can be seen in Table 3. DS15 showed a negative result for this test envisage by the absence of discoloration of the medium to purple. The color change occurs in the medium containing bromocresol purple as an indicator when all oxygen is used up, and anaerobic respiration takes over leading to the production of $\mathrm{CO}_{2}$ and altering the $\mathrm{pH}$ of the medium. The presence of acid will change the indicator color to yellow which means the enzyme decarboxylase has been activated and the reverse will occur when alkaline is produced. Sunatmo, [35] indicated that when the active enzyme produces alkaline diamine (cadaverine) and $\mathrm{CO}_{2}$, it causes the indicator to retain its purple color, which was the same as what was observed for DS15.

Nitrate reduction test was performed to test the ability of DS15 to reduce nitrate $\left(\mathrm{NO}_{3}\right)$ to nitrite $\left(\mathrm{NO}_{2}\right)$. After incubation, organisms that reduce nitrate to nitrite will turn the medium to red color when reagent A which contains sulfanilate and alfa naphthylamine is added. If there is no color change, the bacteria may have nitrate reductase which can reduce nitrite to ammonia or molecular nitrogen. It is therefore necessary to add a bit of $\mathrm{Zn}$ powder to detect whether the nitrate is reduced after the formation of nitrite [35]. If the color turns red, then the bacteria does not reduce nitrate to nitrite. From Table 3, the DS15 isolate showed a negative reaction for the nitrate test.

Generally, LAB has limited biosynthetic capacity [35], but requires complex nutrients such as amino acids, peptides, nucleotide bases, vitamins, minerals and fatty acids [21]. The absence of carbohydrate fermentation during incubation does not mean bacterial isolates do not grow because bacteria can use other nutrients contained in the media as an energy source. As peptone can be converted to amino acids which will be converted by oxidative deamination into ketoamino acids, the substrate will be further metabolized through the Krebs cycle for energy production [35].

The last test conducted to identify the identity of DS15 was gram stain. Gram stain is a differential staining performed to distinguish between gram-positive and gramnegative bacteria. Gram staining of DS15 showed a purplishblue color, indicating that the isolate was a gram-positive bacterium (Fig. 1). For bacteria classified as gram negative, a pink color will be produced.

Gram positive bacterial cell wall is composed of peptidoglycan layer $(90 \%)$ and other small molecules such as ketoic acid, teicuronic acid, polysaccharide, lippotekoic acid, glycolipid and micolate acid [36]. While the gramnegative bacteria have more complex cell wall in the form of peptidoglycan layer $(10 \%)$ and the outer membrane that protects peptidoglycan in the form of phospholipid and lipopolysaccharide [29], [36]. In gram-positive cells, the thickness of the peptidoglycan layer can withstand the purple Iodine crystals (CV-I) complex and the pore becomes smaller due to the dehydration properties of the alcohol so that the cells remain purple [29], [35].

TABLE III

BIOCHEMICAL CHARACTERISTICS OF ISOLATE DS15

\begin{tabular}{|c|l|c|c|l|c|}
\hline No & Characteristic & Results & No & Characteristic & Results \\
\hline 1 & MRSA & + & 12 & Arginine & - \\
\hline 2 & $\begin{array}{l}\text { Aerobe/ } \\
\text { Anaerobe }\end{array}$ & A & 13 & Aesculine & - \\
\hline 3 & TSI & M/M & 14 & Arabinose & - \\
\hline 4 & Catalase & - & 15 & Raffinose & - \\
\hline 5 & Oxidase & - & 16 & Sorbitol & - \\
\hline 6 & Motilities & - & 17 & Trehalase & - \\
\hline 7 & Lactose & - & 18 & Xylose/Maltose & - \\
\hline 8 & Glucose & - & 19 & $\begin{array}{l}\text { Dulcitol/ } \\
\text { Melezitose }\end{array}$ & - \\
\hline 9 & Mannitol & - & 20 & Nitrate & - \\
\hline 10 & VP & - & 21 & Gram & + \\
\hline 11 & OF & - & & & \\
\hline
\end{tabular}




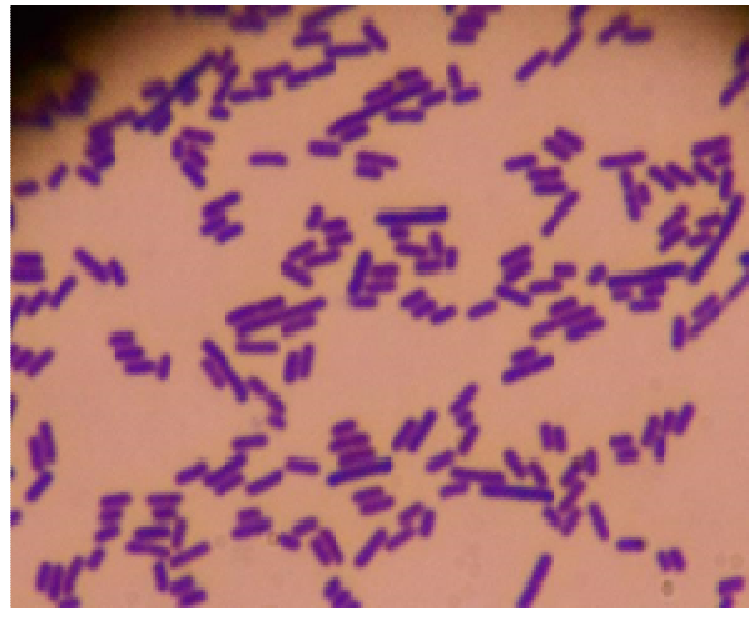

Fig. 1 Gram assay of isolate DS15 under a 1000 x magnification of light microscope.

\section{CONCLUSION}

The research successfully identified 704 isolates from four different West Sumatera indigenous fermented foods. A total of 552 isolates were identified as LAB and 103 among them were able to produce GABA. The isolate DS15 could produce GABA of $49.365 \mathrm{mg} / \mathrm{ml}$, while DS18 produced only $3.415 \mathrm{mg} / \mathrm{ml}$. The isolate DS15 is characterized by its ability to grow on the MRSA, aerobic, do not use lactose, glucose, mannitol, arginine, aesculin, arabinose, raffinose, sorbitol, trehalase, and xylose/melezitose. Moreover, the isolate DS15 do not produce acidic substances, do not reduce nitrate, negative for catalase and oxidase. Based on gram stain reaction, the isolate DS15 was a gram-positive bacterium and classified as Lactobacillus sp.

This study aims to obtain LAB isolates from West Sumatra fermented foods that can produce GABA as antistress. This study helps researchers and industry to produce GABA production. Thus, new lactic acid bacteria isolated from West Sumatra fermented food can be used as a GABA producer which is used as a supplement for feed or additional feed for livestock as an anti-stress.

\section{ACKNOWLEDGMENT}

We are very grateful to the Minister of Research, Technology and Higher Education of the Republic of Indonesia for funding this research through PMDSU No: No: 1387/E4./2015 and the support through World Class Professor Program Scheme-B No. 123.57/D2.3/KP/2018.

\section{REFERENCES}

[1] Reis H.J, Paquet M, Guatimosim C., Palotas A. Peurotransmitters in the central nervous system \& their implication in learning and memory processes. Curr. Medic. Chemist. 16: 796-840. 2009 http://dx.doi.org/10.2174/092986709787549271

[2] Burton A R., Baquet Z., Eisenbarth G.S., Tisch R., Smeyne R., Workman C.J., Vignali DAA. Central nervous system destruction mediated by glutamic acid decarboxylase-specific cd4+ t cells. J $\begin{array}{lll}\text { Immunol. } & \text { 184: } & 4863-4870 .\end{array}$ https://doi.org/10.4049/jimmunol.0903728

[3] Dhakal R., Baipai V.K., Baek K.H. Production of GABA $(\gamma-$ Aminobutyric Acid) by microorganisms: a Review. Braz. J Microbiol. 43: 1230-1241. 2012. http://dx.doi.org/10.1590/S151783822012000400001
[4] Esmaeili A., Ghaed K. GABAA receptors as novel drug targets for treatment of mental disorders. J Paramedi. Sci. 1: 50-61. 2010. ISSN 2008-496X

[5] Suwanmanona K, Chuan HP. Isolating Bacillus subtilis and optimizing its fermentative medium for GABA and nattokinase production. Cyta J Food. 12: 282-290. 2014. http://dx.doi.org/10.1080/19476337.2013.848472

[6] Dai S.F., Gao F., Zhang W.H., Song S.X., Xu X.L., Zhou G.H. Effects of dietary glutamine and gamma-aminobutyric acid on meat colour, $\mathrm{pH}$, composition, and water-holding characteristic in broilers under cyclic heat stress, British Poult. Sci. 45: 471-481. 2012. https://doi.org/10.1080/00071668.2012.719148

[7] Li Y.H., Li F., Liu M., Yin J.J., Cheng B.J., Shi B.M., Shan A.S. Effect of $\gamma$-aminobutyric acid on growth performance, behavior and plasma hormones in weaned pigs. Canadian J Anim. Sci. 95: 165171. 2015. https://doi.org/10.4141/cjas2013-148

[8] Zhao A., Hu Z., Wang X.. Metabolic engineering of Escherichia coli to produce gamma-aminobutyric acid using xylose. Appl. Microbiol. Biotechnol. 101: 3587-3603. 2017 https://doi.org/10.1007/s00253017-8162-3

[9] Higuchi T., Hayashi H., Abe K. Exchange of glutamate and gammaaminobutyrate in a Lactobacillus strain, J Bacteriol. 179: 3362-3364. 1997. ISSN: 1098-5530

[10] Siragusa S., Angelis M.D., Cagno R.D., Rizzello C.G., Coda R., Gobbetti M.. Synthesis of $\gamma$-aminobutyric acid by lactic acid bacteria isolated from a variety of Italian cheeses. Appl. Environ. Microbiol. 73: 7283-7290. 2007. http://doi.org/10.1128/AEM.01064-07

[11] Xue L.X., Yan X.C., Xin G.Z. Optimisation of fermentative parameters for GABA enrichment by Lactococcus lactis, Czech J Food Sci. 27: 433-442. 2009. ISSN 1750-3841

[12] Thwe S.M., Kobayashi T., Luan T., Shirai T., Onodera M., Sato N.H., Imada C. Isolation, characterization, and utilation of $\gamma$-aminobutyric acid (GABA)-producing lactid acid bacteria from Myanmar fishery products fermented with boiled rice. Food Sci. Technol. 77: 279-288. 2011. https://doi.org/10.1007/s12562-011-0328-9

[13] Gupta A., Sharma N. In vitro characterization of lactic acid bacteria isolated from lasoda bari- a rare fermented food of Himachal Pradesh-India for potential probiotic attributes. J Microbiol. Biotechnol. Food Sci. 2017. https://doi.org/10.15414/jmbfs.2017.6.6.1323-1328

[14] Ali F.W.O., Abdulamir A.S., Mohammed A.S., Bakar F.A., Manap Y.A., Zulkifli A.H., Saari N. Novel, practical and cheap source for isolating $\gamma$-aminobutyric acid-producing Leuconostoc NC5 bacteria, Res. J Med. Sci. 3: 146-153. 2009. ISSN 1815-9346

[15] Kook M.C., Cho S.C. Production of GABA (gamma amino butyric acid) by lactic acid bacteria, Korean J Food Sci. 33: 377-389. 2013. https://doi.org/10.5851/kosfa.2013.33.3.377

[16] Spies J.R. Colorimetric procedures for amino acid methods in enzymology. Meth. Enzym. 76: 467-477. 1957. https://doi.org/10.1016/S0076-6879(57)03417-5

[17] Gad G.F.M., Hamid A.M.A., Farag Z.S.H. Antibiotic resistance in lactic acid bacteria isolated from some pharmaceutical and dairy product. Braz. J Microbiol. 45: 25-33. 2014. ISSN 1678-4405

[18] Islam K.N., Akbar T., Akther F., Islam N.N. Characterization and confirmation of lactobacillus spp. from selective regional yoghurts for probiotic and interference with pathogenic bacterial growth. Asian J Biol Sci. 9: 1-9. 2016. https://doi.org/10.3923/ajbs.2016.1.9

[19] Harimurti S., Rahayu E.S., Nasroedin, Kurniasih. Lactic acid bacteria isolated from the Gastro-intestinal tract of chicken: Potential use as probiotic. Anim Prod. 9: 82-91. 2005. ISSN 1411-2017

[20] Julendra H., Suryania A.E., Istiqomaha L., Damayantia E., Anwara M., Fitriani N. Isolation of lactic acid bacteria with cholesterollowering activity from digestive tracts of Indonesia native chickens. $\begin{array}{llll}\text { Media } & \text { Peternakan. } & 40: & 35-41 .\end{array}$ https://doi.org/10.5398/medpet.2017.40.1.35

[21] Khalid K. An overview of lactic acid bacteria. Int. J Biosci. 1: 1-13. 2011. ISSN 2222-5234

[22] Surono I.S., Hosono A. Antimutagenicity of milk cultured with lactic acid bacteria from dadih against mutagenic Teerasi. Milchwissenschaft, 51: 478-487. 1996

[23] Huda N., Ahmad R. Budu and tukai-endemic fermented fish products from West Sumatera. INFOFISH Int. 3. 2006. ISSN 15115976

[24] Montagnac J.A., Davis C.R.. Tanumihardjo S.A. Nutritional value of Cassava for use as a staple food and recent advance for improvement, Compr. Rev. Food Sci. Food Saf. 8: 181-194. 2009. https://doi.org/10.1111/j.1541-4337.2009.00077.x85 
[25] Pato U., Surona I.S. Bile and acid tolerance of lactic acid bacteria isolated from tempoyak and their probiotic potential. J Agricultur. Technol. 9: 1849-1862. 2013. ISSN 1686-914

[26] Li H., Ting Q., Guidong H., Yusheng C. Production of gammaaminobutyric acid by Lactobacillus brevis NCL912 using fed-batch fermentation. Microbila Cell Factories. 9: 85. 2010. https://doi.org/10.1186/1475-2859-9-85

[27] Lee B.J., Kim J.S., Kang Y.M., Lim J.H., Lim Y.M., Kim Y.M., Lee M.S., Jeong M.H., Ahn C.B., Je J.Y. Antioxidant activity and $\gamma-$ aminobutyric acid (GABA) content in sea tangle fermented by Lactobacillus brevis BJ20 isolated from traditional fermented foods. $\begin{array}{llll}\text { Food } & \text { Chem. } & 122 \text { : } & 271-276 .\end{array}$ https://doi.org/10.1016/j.foodchem.2010.02.071

[28] Marlida Y., Harnentis, Nurmiati. Isolation and screening of lactic acid bacteria from dadih for glutamic Acid production as precursor of $\gamma$-Amino Butyric Acid (GABA) induced heat stress in broiler. Int. J Chem. Tech. Research. 9: 534-540. 2016. ISSN 2455-9555

[29] Sunatmo T.I. Mikrobiologi esensial Jilid 1. Ardy Agency, Jakarta. 2009a. ISBN 979-9527-95-3
[30] Ismail Y.S., Yulvizar C., Mazhitov B. Characterization of lactic acid bacteria from local cow's milk kefir, IOP Conf Ser: Earth Environ. Sci, 130: 012019. 2018. http://dx.doi.org/10.1088/17551315/130/1/012019

[31] Nur F., Hafsan, Paramitasari D. Isolasi dan identifikasi bakteri asam laktat berpotensi probiotik dari dangke susu sapi di Kabupaten Enrekang. Jurnal Biotek. 3: 52-66. 2015. ISSN 2354-9106

[32] Guessas B., Kihal M. Characterization of lactic acid bacteria isolated from Algerian arid zone raw goats' milk. African J Biotechnol. 3: 339-342. 2004. http://dx.doi.org/10.5897/AJB2004.000-2062

[33] Adam M.R., Nout R. Fermentation and Food Safety. Aspen Publisher, Washington. 2001. ISBN 0-8342-1843-7

[34] Hemraj V., Diksha S., Avneet G. A review on commonly used biochemical test for bacteria. Innovare J. Life Sci. 1: 1-7. 2013

[35] Sunatmo T.I. Eksperimen mikrobiologi dalam laboratorium. Ardy Agency, Jakarta. 2009b ISBN 979-9527-63-5

[36] Kim S.J., Chang J., Singh M. Peptidoglycan architecture of grampositive bacteria by solid-state NMR. Biochimica Biophysica Acta (BBA)-Biomembranes. $\quad$ 1848: $350-362 . \quad 2015$. https://doi.org/10.1016/j.bbamem.2014.05.031 